Economics Development Analysis Journal 6(2)(2017)

\title{
Strategi Pengelolaan Dana Desa untuk Meningkatkan Kesejahteraan Masyarakat Desa Kalikayen Kabupaten Semarang
}

Depi Rahayu ${ }^{1 凶}$

Jurusan Ekonomi Pembangunan, Fakultas Ekonomi, Universitas Negeri Semarang

\begin{tabular}{l} 
Info Artikel \\
\hline Sejarah Artikel: \\
Diterima Januari 2017 \\
Disetujui Maret 2017 \\
Dipublikasikan Mei 2017 \\
\hline Keywords: \\
Management Strategy, \\
Village Fund, Community \\
Welfare
\end{tabular}

\begin{abstract}
Abstrak
Penelitian ini mengidentifikasi tentang pengelolaan dana desa. Penelitian ini dilakukan di Desa Kalikayen Kecamatan Ungaran Timur Kabupaten Semarang. Penelitian ini dilakukan karena dana desa memiliki implikasi yang sangat besar dan juga signifikan terhadap pembangunan desa di setiap kabupaten yang ada di Indonesia. Jenis penelitian ini menggunakan metode penelitian kuantitatif dengan menggunakan data primer dan data sekunder. Penelitian ini menggunakan alat analisis SWOT. Tujuan dari penelitian ini untuk mengetahui mekanisme pengelolaan dana desa, mengidentifikasi perkembangan infrastruktur setelah adanya dana desa, dan menentukan strategi. Hasil dari penelitian ini menujukan mekanisme pengelolaan dana desa yang dilakukan desa kalikayen sudah sesuai dengan aturan yang ada, perkembangan infrastruktur di desa sudah jauh lebih baik, dan Strategi yang tepat untuk digunakan dalam pengelolaan dana desa yaitu dengan mengefektifkan dana-dana bantuan guna meningkatkan perekonomian serta memanfaatkan SDM yang cukup potensial.
\end{abstract}

\begin{abstract}
This study was to identify the village fund management in the Kalikayen village, East Ungaran sub-district, Semarang regency. This research was conducted for the village fund had huge implications and is also significant to the development of villages in every district in Indonesia. This research uses a quantitative method using primary data and secondary data. This research using SWOT analysis tool. The purpose of this study to determine the mechanism of village fund management, identify infrastructure development after their village funds, and determine the strategy. The results of this study addressed the mechanism of fund management villages conducted village kalikayen are in accordance with existing rules, the development of infrastructure in the village is already much better, and the right strategy to be used in the management of village fund is to streamline assistance funds to support the economy and harness human resources potential.
\end{abstract}




\section{PENDAHULUAN}

Keberadaan desa secara yuridis formal diakui dalam undang-undang nomor 23 tahun 2014 tentang pemerintah Daerah dan peraturan pemerintah nomor 72 tahun 2005 tentang desa. Berdasarkan ketentuan ini desa diberi pengertian sebagai kesatuan masyarakat hukum yang memiliki batas-batas wilayah yang berwenang untuk mengatur dan mengurus kepentingan masyarakat setempat berdasarkan asal usul dan adat istiadat setempat yang diakui dan dihormati dalam sistem pemerintahan Negara Kesatuan Republik Indonesia. Pemahaman desa diatas menempatkan desa sebagai suatu organisasi yang secara politis memiliki kewenangan untuk mengurus dan mengatur warga atau komunitasnya. Pemerintah daerah diberikan hak untuk mengembangkan desa sesuai dengan hakhak kolektif desa (Lai dan Bosin, 2016). Posisi tersebut desa memiliki peran yang sangat penting dalam menunjang kesuksesan pemerintahan nasional secara luas.

Desa menjadi garda terdepan dalam menggapai keberhasilan dari segala urusan dan program dari pemerintah. Hal ini juga sejalan apabila dikaitkan dengan komposisi penduduk Indonesia menurut sensus terakhit pada tahun 2010 bahwa sekitar 50,21\% atau sebgaian besar penduduk Indonesia saat ini masih bertempat tinggal di kawasan pemukiman pedesaan (BPS, 2015). Maka menjadi sangat logis apabila pembangunan desa menjadi prioritas utama bagi kesuksesan pembangunan nasional. Agar dapat melaksanakan perannya dalam mengatur dan mengurus komunitasnya, desa berdasarkan ketentuan peraturan pemerintah nomor 72 tahun 2005 tentang desa, diberikan kewenangan yang mencangkup;

a. Urusan pemerintahan yang sudah ada berdasarkan hak asal usul desa;

b. Urusan pemerintahan yang menjadi kewenangan Kabupaten/Kota yang diserahkan pengaturannya kepada desa;

c. Tugas pembantuan dari Pemerintah, Pemerintah Provinsi, dan Pemerintah Kabupaten/Kota; dan d. Urusan pemerintahan lainnya yang oleh peraturan perundang-undangan diserahkan kepada desa

Sumber pembiayaan pemerintah daerah terdiri dari 3 komponen besar, yaitu: Pendapatan Asli Daerah, yang meliputi: Hasil pajak daerah Hasil restribusi daerah, Hasil perusahaan daerah (BUMD), Lain-lain hasil usaha daerah yang sah, Pendapatan yang berasal dari pusat, meliputi: Sumbangan dari pemerintah, Sumbangansumbangan lain yang diatur dengan peraturan perundang - undanganLain-lain pendapatan daerah yang sah. Diantara ketiga komponen sumber pendapatan tersebut, komponen kedua yaitu pendapatan yang berasal dari pusat merupakan cerminan atau indikator dari ketergantungan pendanaan pemerintah daerah terhadap pemerintah pusat. Disamping itu besarnya dana dari pusat tersebut juga membawa konsekuensi kepada kebijakan proyek pemerintah pusat yang secara fisik implementasinya itu berada di daerah. Sehingga ada beberapa proyek pemerintah pusat yang dilaksanakan di daerah yang dibiayai oleh pemerintah pusat melalui APBN tetapi dana itu juga masuk di dalam anggaran pemerintah daerah (APBD) (Suseno, 2013).

Sebagai konsekuensi logis adanya kewenangan dan tuntutan dari pelaksanaan otonomi desa adalah tersedianya dana yang cukup. Wasistiono $(2006 ;$ 107) menyatakan bahwa pembiayaan atau keuangan merupakan faktor essensial dalam mendukung penyelenggaraan otonomi desa, sebagaimana juga pada penyelenggaraan otonomi daerah. Sejalan dengan pendapatan yang mengatakan bahwa "autonomy" identik dengan "auto money", maka untuk mengtur dan mengurus rumah tangganya sendiri desa membutuhkan dana atau biaya yang memadai sebagai dukungan pelaksanaan kewenangan yang dimilikinya. Dalam operasionalisasi Desa untuk mewujudkan otonomi yang diberikan kepada desa terdapat pembiayaan-pembiayaan, dimana pembiayaan tersebut memiliki hubungan dengan Dana Desa, Hal ini tercantum pada UndangUndang Nomor 6 Tahun 2014 tentang Desa. UU Desa juga memberikan jaminan yang lebih 
pasti bahwa setiap desa akan menerima dana dari pemerintah melalui anggaran negara dan daerah yang jumlahnya berlipat, jauh diatas jumlah yang selama ini tersedia dalam anggaran desa.

Pengalokasian Dana Desa kepada Kabupaten/Kota berdasarkan jumlah desa dengan memperhatikan jumlah penduduk, angka kemiskinan, luas wilayah, dan tingkat kesulitan geografis. Dana Desa digunakan untuk mendanai keseluruhan kewenangan desa dengan prioritas untuk mendukung program pembangunan desa dan pemberdayaan masyarakat desa.

Pada penelitian ini mengkaji mengenai Dana Desa pada wilayah Desa Kalikayen. Dari sekian banyak desa yang ada di Indonesia, banyak yang belum begitu mengembangkan serta memanfaatkan Dana Desa sesuai yang diharapkan masyarakat seperti yang terjadi di Desa Kalikayen. Lemahnya infrastruktur dan kemampuan organisasi pemerintah desa dalam pengelolaan dana menyebabkan desa kalikayen menjadi tertinggal dan tidak berkembang. Hal inilah yang jadi pengaruh besar bagi masyarakat dalam rangka menumbuhkan ekonomi yang baik untuk kesejahteraan hidup.

Mengenai hal tersebut tentunya akan memunculkan berbagai permasalahan yang sangat menarik untuk dikaji berkaitan dalam proses pengelolaan Dana Desa. Peneliti memiliki alasan tersendiri dalam memilih program Dana Desa dibandingkan dengan program lain yang diprogramkan oleh pemerintah. Ketertarikan ini dikarenakan program Dana Desa memiliki implikasi yang sangat besar dan juga signifikan terhadap pembangunan sebuah desa/kelurahan di setiap kabupaten yang ada di Indonesia. Kendali dalam program ini juga sepenuhnya ditangani secara swadaya oleh pemimpin daerah dan juga masyarakat langsung. Oleh sebab itu, peneliti lebih memilih meneliti mengenai program ini karena jika dana ini dikelola secara jujur, maka hasil pembangunan juga terlihat dengan jelas, dan juga sebaliknya.
Adapun tujuan dari penelitian ini yaitu mengidentifikasi mekanisme pengelolaan dana desa di Desa Kalikayen; mengidentifikasi perkembangan infrastruktur di Desa Kalikayen kecamatan Ungaran Timur Kabupaten Semarang setelah adanya Dana Desa; menentukan strategi yang akan dilakukan dalam upaya meningkatan kesejahteraan masyarakat desa.

\section{METODE PENELITIAN}

Metode yang digunakan dalam penelitian ini adalah kuantitatif dengan menggunakan data primer dan sekunder yang berkaitan dengan pengelolaan dana desa di Desa Kalikayen tahun 2015. Teknik pengambilan sampel adalah Purposive Sampling dengan 1 responden dari pegawai bapermades, dan 11 responden perangkat Desa Kalikayen. Analisis yang digunakan untuk menetukan strategi menggunakan analisis SWOT.

\section{HASIL DAN PEMBAHASAN}

\section{Mekanisme Pengelolaan Dana Desa Di Desa Kalikayen}

Sesuai dengan peraturan Undang-Undang Nomor 6 Tahun 2014 tentang Desa dan selanjutnya ditindaklanjuti dengan Peraturan Pemerintah Nomor 43 Tahun 2014 tentang Peraturan Pelaksanaan Undang-Undang Nomor 6 Tahun 2014 tentang Desa. Maksud dari alokasi dana desa ini guna untuk meningkatkan kemampuan keuangan desa guna membiayai program pemerintah desa dalam melaksanakan kegiatan bidang pemerintahan desa, pelaksanaan pembangunan desa, pembinaan masyarakat desa dan pemberdayaan masyarakat desa. Desa mempunyai hak untuk memperoleh alokasi dana desa. Adapun mekanisme dalam pengelolaan dana desa di Desa Kalikayen sebagai berikut: 


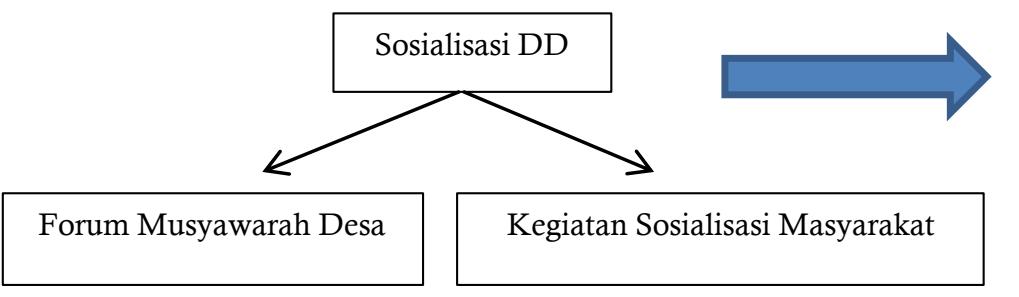

Penyusunan RAB oleh:

1. BPD

2. LKD

3. Toko Masyarakat

4. Kepala Desa
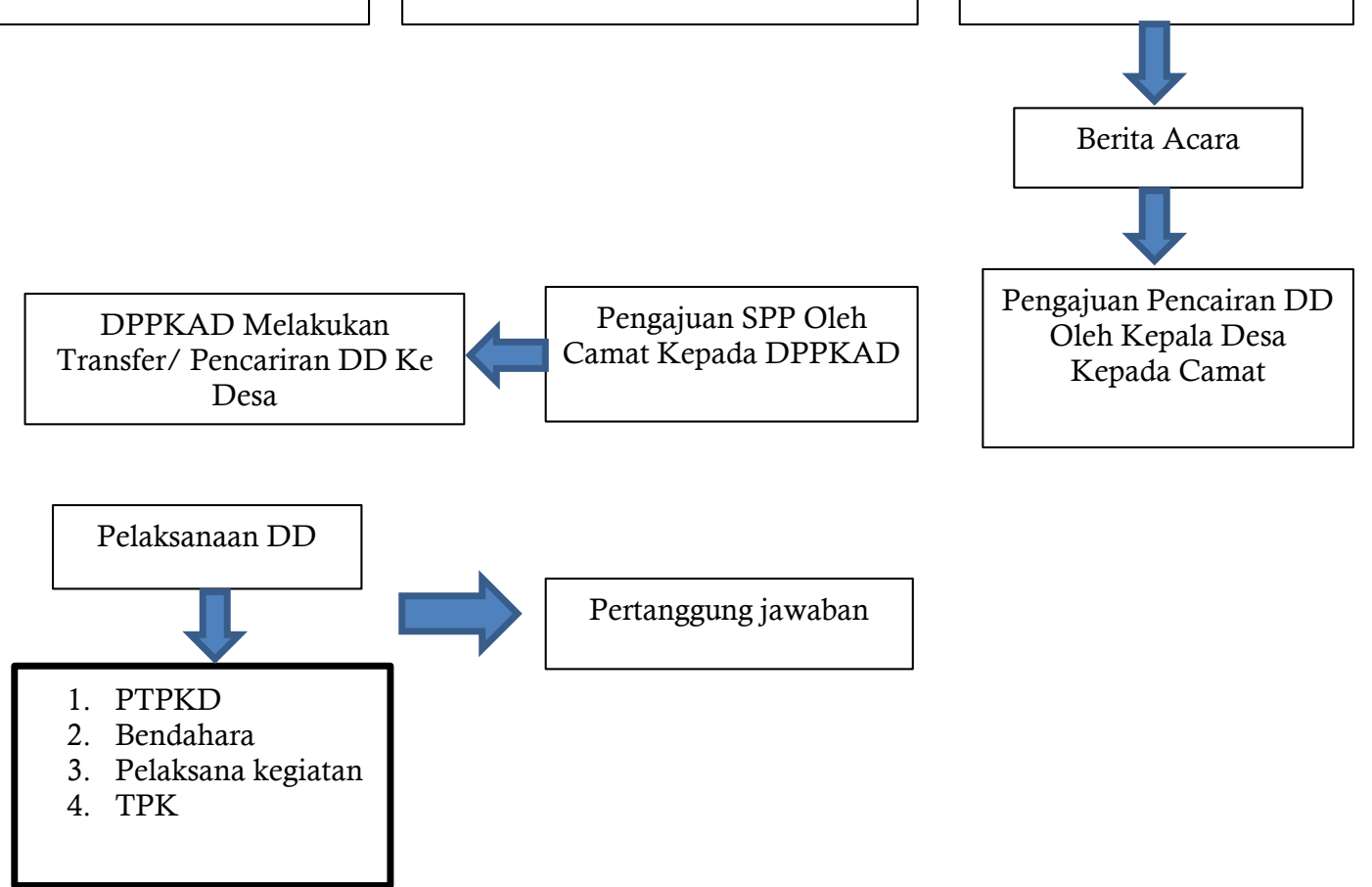

Gambar 1. Mekanisme Pengelolaan Dana Desa

Dana Desa diprioritaskan untuk membiayai pembangunan dan pemberdayaan masyarakat yang sesuai dengan prioritas yang ditetapkan dalam Peraturan Menteri Desa, Pembangunan Daerah Tertinggal Dan Transmigrasi Republik Indonesia Nomor 21 Tahun 2015 tentang Penetapan Prioritas Penggunaan Dana Desa. Namun sejauh ini prioritas pengelolaan dana desa di Desa Kalikayen dialokasikan untuk pembangunan infrastruktur desa seperti pembangunan saluran/irigasi, kegiatan pavingisasi jalan lingkungan desa, perbaikan jembatan desa, betonisasi, pembangunan talud jalan desa, dan pembangunan gorong-gorong. Lokasi desa dengan aksesibilitas transportasi yang baik lebih mudah untuk dikembangkan karena akan diintegrasikan ke daerah perkotaan (Lai dan Xiaoling, 2016).

Perkembangan Infrastruktur Desa Kalikayen Setelah Adanya Dana Desa

Kondisi infrastruktur di Desa Kalikayen sebelum adanya dana desa sejauh itu sangat memprihatinkan. Lemahnya infrastruktur desa menyebabkan Desa Kalikayen menjadi tertinggal dan tidak berkembang. Namun setelah adanya dana desa, Infrastruktur di Desa Kalikayen mengalami perubahan. Adanya pembangunan dan perbaikan infrastruktur di Desa Kalikayen merupakan wujud dari implementasi dana desa. hal tersebut di buktikan dari hasil wawancara penulis dengan perangkat desa dan masyrakat Desa Kalikayen mengenai perubahan infrastruktur desa sebelum dan sesudah adanya dana desa pada tabel 3 berikut : 
Tabel 1. Perbandingan Infrastruktur Di Desa Kalikayen Sebelum Dan Sesudah Adanya Dana Desa

\begin{tabular}{|c|c|}
\hline $\begin{array}{l}\text { Kondisi Sebelum Adanya } \\
\text { Dana Desa }\end{array}$ & $\begin{array}{l}\text { Kondisi Sesudah Adanya } \\
\text { Dana Desa }\end{array}$ \\
\hline $\begin{array}{l}\text { 1. Kondisi jalan desa yang masih kurang baik } \\
\text { 2. Kondisi jembatan desa yang rusak parah } \\
\text { 3. Tidak ada transportasi desa } \\
\text { 4. Saluran irigasi yang masih kurang baik } \\
\text { 5. Jalan desa belum di beton } \\
\text { 6. Belum ada pembangunan talud jalan } \\
\text { 7. Belum adanya pembangunan gorong- } \\
\text { gorong }\end{array}$ & $\begin{array}{l}\text { 1. Perbaikan dan pavingisasi jalan lingkungan } \\
\text { desa } \\
\text { 2. Jembatan desa sudah diperbaiki kondisi } \\
\text { jembatan jauh lebih baik } \\
\text { 3. Sudah ada transportasi umum } \\
\text { 4. Perbaikan dan pembangunan saluran irigasi } \\
\text { 5. Jalan desa segaian sudah di betonisasi } \\
\text { 6. Adanya pembangunan talud jalan } \\
\text { 7. Sudah dilakukan pembangunan gorong- } \\
\text { gorong }\end{array}$ \\
\hline
\end{tabular}

Sumber: Data Primer

Strategi Pengelolaan Dana Desa Untuk Meningkatkan Kesejahteraan Masyarakat Desa Kalikayen

Analisis strategi yang tepat dalam meningkatkan kesejahteraan masyarakat di Desa Kalikayen dengan melakukan analisis SWOT. Analisis SWOT menggunakan berbagai model analisis dengan tahapan Identifikasi faktor internal (IFAS) dan Identifikasi faktor eksternal (EFAS) dalam pengelolaan dana desa. Berdasarkan hasil identifikasi terhadap faktor internal dalam pengelolaan dana desa, maka diperoleh kekuatan dan kelemahan yang terdapat pada pengelolaan dana desa di Desa Kalikayen yaitu:

Tabel 2. Analisis Matrik IFAS Pengelolaan Dana Desa di Desa Kalikayen

\begin{tabular}{|c|c|c|c|}
\hline Faktor-faktor strategi internal & Rating (R) & Bobot (B) & Skor (R x B) \\
\hline \\
\hline $\begin{array}{l}\text { Memiliki sistem informasi yang cukup baik (pedoman } \\
\text { pelaksanaan \& peraturan tentang Dana Desa) }\end{array}$ & 4 & 0,15 & 0,58 \\
\hline $\begin{array}{l}\text { Memiliki SDM yang berusia muda dan potensial untuk } \\
\text { dikembangkan }\end{array}$ & 3 & 0,11 & 0,32 \\
\hline $\begin{array}{l}\text { Antusias masyarakat sekitar yang senang dengan adanya } \\
\text { bantuan Dana Desa }\end{array}$ & 3 & 0,09 & 0,26 \\
\hline Masih banyak potensi desa yang masih bisa dikembangkan & 4 & 0,08 & 0,32 \\
\hline Adanya pendamping desa & 3,5 & 0,11 & 0,39 \\
\hline \multicolumn{2}{|l|}{ Total kekuatan } & 0,53 & 1,88 \\
\hline \multicolumn{4}{|l|}{ Kelemahan : } \\
\hline Sarana dan prasarana fisisk yang tersedia relatif sulit & 1,5 & 0,08 & 0,12 \\
\hline $\begin{array}{l}\text { Kompetensi SDM perangkat desa yang lemah dibidang } \\
\text { pengelolaan dana }\end{array}$ & 1,5 & 0,16 & 0,23 \\
\hline Kurangnya kemampuan pembangunan desa & 1,5 & 0,08 & 0,13 \\
\hline Kurangnya kesadaran masyarakat untuk memajukan desa & 1,5 & 0,15 & 0,22 \\
\hline \multicolumn{2}{|l|}{ Total kelemahan } & 0,47 & $\mathbf{0 , 7 0}$ \\
\hline \multicolumn{3}{|l|}{ Total faktor-faktor strategi internal (kekuatan - kelemahan) } & 1,18 \\
\hline
\end{tabular}


Sumber : Data Primer, Diolah

Berdasarkan tabel 4 diatas, dapat digunakan untuk membandingkan diketahui skor dari hasil perkalian bobot dan perkembangan desa sebelum dan sesudah rating faktor strategi internal. Terlihat dari hasil adanya dana desa. Berdasarkan hasil identifikasi perhitungan tersebut desa kalikayen dalam terhadap faktor eksternal (EFAS) pengelolaan mengelola dana desa memiliki kekuatan yang dana desa di Desa Kalikayen maka diperoleh dominan dibandingkan dengan kelemahannya. beberapa peluang dan ancaman. Peluang dan Hasil tersebut menunjukan bagaimana ancaman bagi Desa Kalikayen dalam pengelolaan dana desa bereaksi terhadap faktormengelolaan dana desa adalah:

faktor strategi internalnya. Skor total ini dapat

Tabel 3. Analisis Matrik EFAS Pengelolaan Dana Desa di Desa Kalikayen

\begin{tabular}{l|l|l|l}
\hline \multicolumn{1}{c|}{ Faktor-faktor strategi eksternal } & \multicolumn{1}{c|}{$\begin{array}{c}\text { Rating } \\
(\mathbf{R})\end{array}$} & $\begin{array}{c}\text { Bobot } \\
(\mathbf{B})\end{array}$ & $\begin{array}{c}\text { Skor (B } \mathbf{x} \\
\mathbf{R})\end{array}$ \\
\hline $\begin{array}{l}\text { Peluang : } \\
\text { Adanya dukungan dari pemerintah }\end{array}$ & 3,5 & 0,17 & 0,58 \\
$\begin{array}{l}\text { Meningkatkan kesejahteraan masyarakat } \\
\text { Memiliki kewenangan untuk mengatur dan mengurus }\end{array}$ & 2,5 & 0,12 & 0,30 \\
sendiri pengelolaan pemerintahannya & & 0,17 & 0,58 \\
Memperbaiki sarana dan prasarana infrastruktur desa & 4 & 0,17 & 0,67 \\
\hline Total peluang & & 0,62 & 2,13 \\
\hline Ancaman : & 1,5 & 0,21 & 0,32 \\
Ketidak pastian proses pencairan Dana Desa & 2,5 & 0,21 & 0,54 \\
$\begin{array}{l}\text { Tingkat keberhasilan program yang telah direncanakan } \\
\text { tidak sesuai yang diharapkan }\end{array}$ & 1,5 & 0,21 & 0,32 \\
Berkurangnya anggaran dari pemerintah & $\mathbf{0 , 4 3}$ & $\mathbf{1 , 1 8}$ \\
\hline Total ancaman & & $\mathbf{0 , 1 9}$ \\
\hline Total faktor-faktor strategi eksternal (ancaman - peluang)
\end{tabular}

Sumber : Data Primer, Diolah

Berdasarkan tabel 5 diatas, dapat diketahui skor dari hasil perkalian bobot dan rating faktor strategi eksternal. Terlihat dari hasil perhitungan tersebut desa kalikayen dalam mengelola dana desa memiliki peluang yang dominan dibandingkan dengan ancamannya. hasil tersebut menunjukan bagaimana pengelolaan bereaksi terhadap faktor-faktor strategi eksternalnya. Skor total ini dapat digunakan untuk membandingkan perkembangan desa kalikayen sebelum dan sesudah adanya dana desa. Apabila hasil perhitungan analisis faktor strategi internal dan faktor strategi eksternal tersebut dimasukan dalam matrix Grand Strategi terlihat pengelolaan dana desa di Desa Kalikayen pada posisi strategi pertumbuhan yaitu memanfaatkan kekuatan dan peluang seoptimal mungkin. 
Depi Rahayu/ Economics Development Analysis Journal 6 (2) (2017)

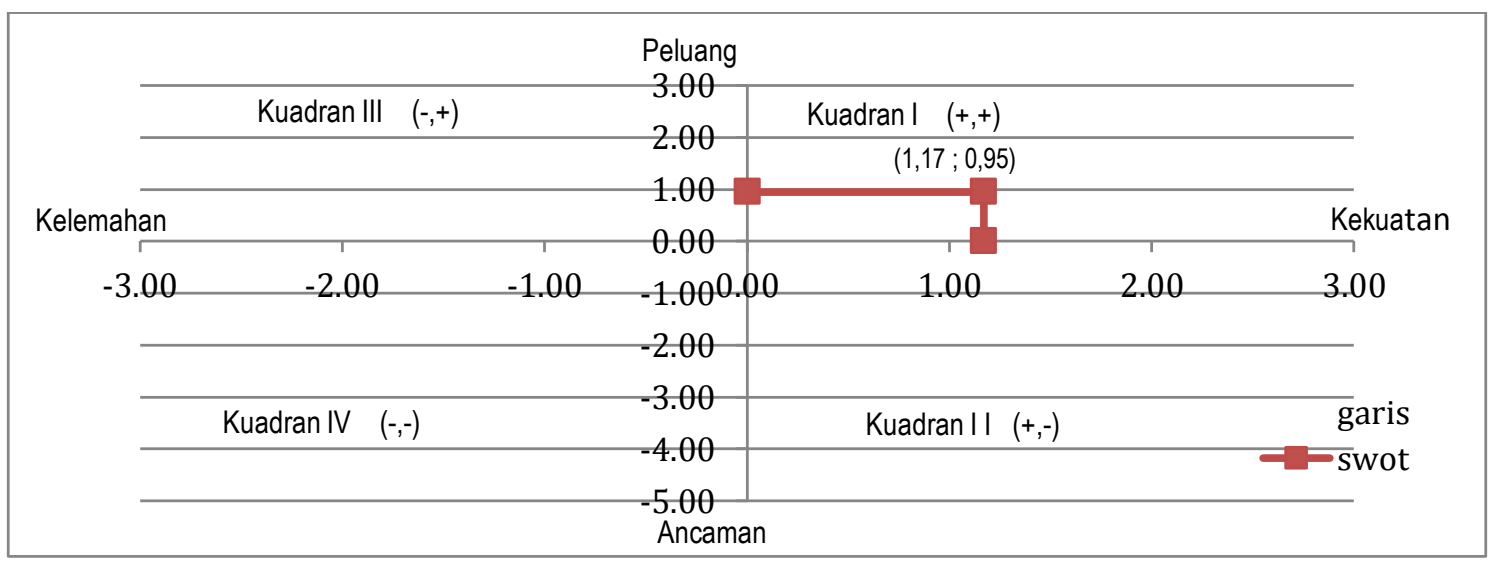

Gambar 2. Matrix Grand Strategi

Sumber : Data Primer, Diolah

Gambar 2. menunjukan total skor faktor internal-eksternal, skor pembobotan yang diperoleh dari faktor internal adalah 1,18 dan faktor eksternal memperoleh skor pembobotan sebesar 0,19 , hal tersebut menunjuk titik kordinat terletak pada daerah kuadran I ini merupaka situasi yang sangat menguntungkan. Strategi yang tepat digunakan untuk pengelolaan dana desa di Desa Kalikayen adalah mendukung kebijakan pertumbuhan yang agresif (growth oriented strategy). Artinya organisasi dalam kondisi prima dan mantap sehingga sangat dimungkinkan untuk terus melakukan ekspansi, memperbesar pertumbuhan dan meraih kemajuan secara maksimal. Hasil dari analisis SWOT tersebut dapat diuraikan secara rinci menggunakan matrik SWOT. Berikut ini adalah matrik SWOT yang diolah berdasarkan identifikasi kekuatan, kelemahan, peluang, dan ancaman yang dimiliki Desa Kalikayen.

Tabel 4. Analisis Matriks SWOT

\begin{tabular}{|c|c|c|}
\hline & Strength (S) & Weaknesses (W) \\
\hline Ekste & $\begin{array}{l}\text { a. Memiliki sistem informasi yang cukup } \\
\text { baik (pedoman pelaksanaan \& peraturan } \\
\text { tentang Dana Desa) } \\
\text { b. Memiliki SDM yang berusia muda dan } \\
\text { potensial untuk dikembangkan } \\
\text { c. Antusias masyarakat sekitar yang } \\
\text { senang dengan adanya bantuan Dana } \\
\text { Desa } \\
\text { d. Masih banyak potensi desa yang masih } \\
\text { bisa dikembangkan } \\
\text { e. Adanya pendamping desa }\end{array}$ & $\begin{array}{l}\text { a. Sarana dan prasarana fisisk yang } \\
\text { tersedia relatif sulit } \\
\text { b. Kompetensi SDM perangkat desa } \\
\text { yang lemah dibidang pengelolaan } \\
\text { dana } \\
\text { c. Kurangnya } \\
\text { pembangunan desa } \\
\text { d. Kurangnya kesadaran masyarakat } \\
\text { untuk memajukan desa }\end{array}$ \\
\hline Opportunities (0) & Srategi SO & Strategi WO \\
\hline $\begin{array}{l}\text { a. Kebijakan pemerintah } \\
\text { untuk mempercepat } \\
\text { pembangunan } \\
\text { b. Meningkatkan } \\
\text { kesejahteraan } \\
\text { masyarakat dan } \\
\text { perekonomian dengan }\end{array}$ & $\begin{array}{l}\text { 1. Mengefektifkan dana-dana bantuan guna } \\
\text { meningkatkan perekonomian serta } \\
\text { memanfaatkan SDM yang cukup } \\
\text { potensial }\left(\mathrm{S}_{2}, \mathrm{O}_{1}, \mathrm{O}_{2}\right) \\
\text { 2. Meningkatkan akses kerjasama yang } \\
\text { baik antara pemerintah pusat dengan } \\
\text { pemerintah desa yang dituangkan dalam }\end{array}$ & $\begin{array}{l}\text { 1. Strategi pembangunan sarana dan } \\
\text { prasarana }\left(\mathrm{W}_{1}, \mathrm{O}_{4}\right) \\
\text { 2. Strategi peningkatan kualitas SDM } \\
\left(\mathrm{W}_{2}, \mathrm{O}_{3}\right) \\
\text { 3. Program pemberdayaan masyarakat } \\
\left(\mathrm{W}_{3}, \mathrm{~W}_{4}, \mathrm{O}_{1}, \mathrm{O}_{2}, \mathrm{O}_{3}\right)\end{array}$ \\
\hline
\end{tabular}




\begin{tabular}{|c|c|c|}
\hline $\begin{array}{l}\text { memanfaatkan potensi } \\
\text { yang ada } \\
\text { c. Membuka peluang kerja } \\
\text { baru } \\
\text { d. Memperbaiki sarana dan } \\
\text { prasarana infrastruktur } \\
\text { desa }\end{array}$ & $\begin{array}{l}\text { suatu kebijakan pembangunan } \\
\left(\mathrm{S}_{1}, \mathrm{~S}_{5}, \mathrm{O}_{1}, \mathrm{O}_{4}\right) \\
\text { 3. Menciptakan atau meningkatkan } \\
\text { kesempatan berusaha dan lapangan } \\
\text { kerja }\left(\mathrm{S}_{4}, \mathrm{O}_{3}\right)\end{array}$ & \\
\hline Treats $(\mathrm{T})$ & Strategi ST & Strategi WT \\
\hline $\begin{array}{l}\text { a. Ketidak pastian proses } \\
\text { pencairan Dana Desa } \\
\text { b. Tingkat keberhasilan } \\
\text { program yang telah } \\
\text { direncanakan tidak } \\
\text { sesuai yang diharapkan } \\
\text { c. Berkurangnya anggaran } \\
\text { dari pemerintah }\end{array}$ & $\begin{array}{l}\text { 1. Pengkoordinasian antara pengelola dana } \\
\text { desa dengan pendamping desa }\left(S_{5}, T_{2} \text {, }\right. \\
\left.T_{3}\right) \\
\text { 2. Pemanfaatan fasilitas pemerintah berupa } \\
\text { pedoman pelaksanaan dana desa }\left(S_{1} \text {, }\right. \\
\left.W_{1}\right)\end{array}$ & $\begin{array}{l}\text { 1. Meningkatkan kualitas sumber daya } \\
\text { manusia aparatur pemerintah }\left(W_{2} \text {, }\right. \\
\left.T_{2}, T_{3}\right) \\
\text { 2. Meningkatkan peran serta } \\
\text { masyarakat di dalam pembangunan } \\
\left(W_{3}, W_{4}, T_{2}\right)\end{array}$ \\
\hline
\end{tabular}

Sumber : Data primer, Diolah

Mekanisme Pengelolaan Dana Desa Di Desa Kalikayen

Proses pembangunan desa merupakan mekanisme dari keinginan masyarakat yang dipadukan dengan masyarakat. Perpaduan tersebut menentukan keberhasilan pembangunan seperti yang dikemukakan oleh Ahmadi (2001:222) mekanisme pembangunan desa adalah merupakan perpaduan yang serasi antara kegiatan partisipasi masyarakat dalam pihak dan kegiatan pemerintah di satu pihak. Bahwa pada hakekatnya pembangunan desa dilakukan oleh masyarakat sendiri. Sedangkan pemerintah memberikan bimbingan, bantuan, pembinaan, dan pengawasan. Filosofi Dana Desa itu sendiri bertujuan untuk meningkatkan kesejahteraan masyarakat dan pemerataan pembangunan desa melalui peningkatan pelayanan publik di desa, memajukan perekonomian desa, mengatasi kesenjangan pembangunan antar desa serta memperkuat masyarakat desa sebagai subjek dari pembangunan. Namun hal tersebut belum terjadi pada Desa Kalikayen. Desa Kalikayen belum mampu mewujudkan filosofi dari tujuan Dana Desa itu sendiri.

Sejauh ini pengalokasian dana dalam program pembangunan desa di Desa Kalikayen belum merata secara keseluruhan baik dibidang pembangunan desa maupun dibidang pemberdayaan masyarakat. Menurut Permendes
Nomor 21 tahun 2015, prioritas penggunaan dana desa diarahkan untuk pelaksanaan kegiatan pembangunan desa dan kegiatan bidang pemberdayaan masyarakat desa. Pengelolaan dana desa di Desa Kalikayen sejauh ini diprioritaskan untuk pembangunan infrastruktur desa seperti betonisasi jalan poros desa, pavingisasi gang-gang desa, perbaikan jembatan, pembangunan talud jalan, dan gorong-gorong. Hal tersebut sesuai dengan bagian kesatu pasal 6 Peraturan Menteri Desa nomor 21 tahun 2015 tentang penetapan prioritas dana desa. Adapun prioritas penggunaan dana desa yang belum diterapkan atau dilaksanakan oleh Desa Kalikayen sendiri yaitu dalam bidang pemberdayaan masyarakat yang nantinya dana tersebut dialokasikan untuk mendanai kegiatan yang bertujuan meningkatkan kapasitas warga atau masyarakat desa dalam pembangunan wirausaha, peningkatan pendapatan, serta perluasan skala ekonomi individu warga atau kelompok masyarakat dan desa.

\section{Perkembangan Infrastruktur Desa Kalikayen Setelah Adanya Dana Desa}

Dana Desa merupakan program pertama kali yang diluncurkan di Indonesia sebagai salah satu bagian dari tujuan negara untuk membangun desa dalam upaya meningkatkan kualitas hidup dan mensejahterakan masyarakat 
desa. Program dana desa sangat dibutuhkan oleh desa guna untuk mendanai penyelenggaraan pemerintahan, pelaksanaan pembangunan, pembinaan kemasyarakatan, dan pemberdayaan masyarakat. faktor yang mempengaruhi dalam pengelolaan dana desa di Desa Kalikayen antara lain terdapat pada lingkungan internal dan eksternal. Lingkungan internal merupakan cerminan kekuatan dan kelemahan dari suatu organisasi dari pemerintah desa dan dapat dicerminkan kemampuan manajemen untuk mengelola dana. Hal ini dapat menunjukan kekuatan sumber daya manusia, meliputi segala aspek material dan non material yang dimilik pemerintah desa dalam mengelola dana desa.

Sejak digulirkannya bantuan dana desa di desa kalikayen pada tahun 2015, tampak adanya perubahan pada infrastruktur desa. Dimana kondisi infrastruktur desa sebelumnya sangat memprihatinkan seperti jalan desa yang rusak parah, kondisi jembatan penghubung desa yang sudah tidak layak digunakan, kemudian sarana dan prasarana desa yang relatif sulit serta keberadaan desa masih tertinggal. Namun setelah adanya bantuan Dana Desa di Desa Kalikayen ini tampak adanya kegiatan pengelolaan Dana Desa berupa pembangunan fisik seperti perbaikan saluran/ irigasi, kegiatan pavingisasi, pembangunan jembatan, betonisasi, pembangunan talud jalan, dam pembangunan gorong-gorong.

\section{Strategi Pengelolaan Dana Desa Untuk Meningkatkan Kesejahteraan Masyarakat Desa Kalikayen}

Hasil identifikasi kekuatan, kelemahan, peluang serta ancaman yang dimiliki Desa Kalikayen dalam pengelolaan dana desa yang di analisis menggunakan SWOT. Identifikasi diperoleh dari hasil wawancara yang mendalam kepada Kantor Bapermades Kabupaten Semarang, Kantor Kecamatan Ungaran Timur, Perangkat Desa Kalikayen, dan Masyarakat setempat. Dari hasil identifikasi tersebut, dapat dirumuskan strategi pengelolaan Dana Desa untuk meningkatkan kesejahteraan masyarakat dengan analisis SWOT. Hasil analisis didasarkan pada logika yang dapat memaksimalkan kekuatan dan peluang, serta secara bersamaan dapat meminimalkan kelemahan dan ancaman. Sehingga diperoleh rumusan strategi dalam upaya peningkatan kesejahteraan masyarakat desa melalui pengelolaan Dana Desa. strategi antara lain adalah sebagai berikut :

1. Mengefektifkan dana-dana bantuan guna meningkatkan perekonomian serta memanfaatkan SDM yang cukup potensial

2. Meningkatkan akses kerjasama yang baik antara pemerintah pusat dengan pemerintah desa yang dituangkan dalam suatu kebijakan pembangunan

3. Menciptakan atau meningkatkan kesempatan berusaha dan lapangan kerja dengan bekerjasama dengan pihak luar sebagai upaya untuk mendorong tumbuhnya pusat kegiatan ekonomi baru dengan tetap memperhatikan produk lokal desa.

4. Strategi pembangunan sarana dan prasarana di Desa

5. Strategi peningkatan kualitas SDM

6. Program pemberdayaan masyarakat

7. Pengkoordinasian antara pengelola dana desa dengan pendamping desa.

8. Pemanfaatan fasilitas pemerintah berupa pedoman pelaksanaan dana desa

9. Meningkatkan kualitas sumber daya manusia aparatur pemerintah

10. Meningkatkan peran serta masyarakat di dalam pembangunan

Rumusan strategi yang dihasilkan digunakan untuk menata pengelolaan Dana Desa agar dapat meningkatkan kesejahteraan masyarakat desa. Sejalan dengan konsep strategi yang di kemukakan oleh David (2006: 12) dimana strategi merupakan suatu cara yang digunakan dalam menjalankan organisasi sehingga apa yang di inginkan organisasi dapat di capai sesuai dengan misi dan tujuan organisasi tersebut. Dengan kata lain strategi merupakan alat yang digunakan untuk mencapai tujuan jangka panjang yang sudah ditetapkan. Salah satu strategi yang perlu diterapkan adalah dengan melibatkan masyarakat sebagai subjek utama pembangunan (Sesotyaningtyas dan Asnawi, 2015). Dalam pengelolaan Dana Desa strategi yang dirumuskan mencakup 
pembenahan infrastruktur maupun perbaikan SDM perangkat desa itu sendiri agar dapat mencapai tujuan untuk meningkatkan kesejahteraan masyarakat desa, melibatkan masyarakat dalam pembangunan desa karena masyarakat tidak hanya bisa dijadikan sebagai objek pembangunan melainkan sebagai subjek pembangunan, serta peran pemerintah sebagai fasilitator dalam hal pendanaan.

\section{SIMPULAN}

Berdasarkan hasil analisis dan pembahasan pada penelitian yang penulis temukan, maka dapat disimpulkan bahwa mekanisme Pengelolaan Dana Desa di Desa Kalikayen ini sudah sesuai dengan petunjuk teknis pengelolaan Dana Desa, Namun hasil dari pengelolaan Dana Desa tersebut belum mampu meningkatkan kesejahteraan masyarakat secara maksimal dikarenakan pengalokasian dana hanya ditunjukan untuk pembangunan dan perbaikan infrastruktur fisik saja. Perkembangan infrastruktur Desa setelah adanya Dana Desa saat ini jauh lebih baik dibandingkan dari kondisi sebelumnya. Strategi yang dilakukan dalam upaya peningkatan kesejahteraan masyarakat desa melalui pengelolaan Dana Desa antara lain adalah sebagai berikut: mengefektifkan danadana bantuan guna meningkatkan perekonomian serta memanfaatkan SDM yang cukup potensial, meningkatkan akses kerjasama yang baik antara pemerintah pusat dengan pemerintah desa yang dituangkan dalam suatu kebijakan pembangunan.

Saran yang dapat diajukan yaitu untuk mengoptimalkan pembangunan maka pemerintah desa perlu memperhatikan dan mengalokasikan kegiatan pembangunan yang ada pada wilayah-wilayah yang menjadi prioritas dan Pemerintah desa harus lebih terbuka dan aspiratif dalam melihat faktor faktor eksternal maupun internal untuk merumuskan strategi pembangunan daerah kedepannya, sehingga peningkatan pembangunan dan mengurangi ketertinggalan bisa tercapai.

\section{DAFTAR PUSTAKA}

Ahmadi, A, Uhbiyati, N. (2001).Ilmu pendidikan. Jakarta : Rineka Cipta.

David, F. R. (2002). Manajemen Strstegi. Jakarta: Prehalindo.

Lai, Yani \& Bosin Tang. 2016. Institutional Barriers to Redevelopment of Urban Villages in China: A Transaction Cost Persepective. Land Use Policy, Volume 58, Pages 482-490.

Lai, Yani \& Xiaoling Zhang. 2016. Redevelopment of Industrial Sites in The Chinese 'Villages in the City': an Empirical Study of Shenzhen. Journal of Cleaner Production, Volume 134, Pages 70-77.

Peraturan Pemerintah Republik Indonesia Nomor 72 Tahun 2005 tentang Desa. 30 Desember 2005. Desa. Lembaran Negara Republik Indonesia Tahun 2005 Nomor 158. Jakarta.

Peraturan Pemerintah Republik Indonesia Nomor 43 Tahun 2014 tentang Peraturan Pelaksanaan Undang-Undang Nomor 6 Tahun 2014 Tentang Desa. 30 Mei 2014. Lembaran Negara Republik Indonesia Tahun 2014 Nomor 123. Jakarta.

Peraturan Menteri Desa Nomor 21 Tahun 2015 Tentang Penetapan Prioritas Penggunaan Dana Desa.

Sesotyaningtyas, Mega \& Asnawi Manaf. 2015. Analysis of Sustainable Tourism Village Development at Kutoharjo Village, Kendal Regency of Central Java. Social and Behavioral Sciences, Volume 184, Pages 273-280.

SUSENO, Deky Aji. Efektivitas Dan Kemandirian Keuangan Daerah Provinsi Jawa Tengah Pasca Diterapkannya Desentralisasi Fiskal. Economics Development Analysis Journal, [S.1.], v. 2, n. 2, june 2013. ISSN 2252-6560.

Undang-Undang Republik Indonesia Nomor 6 tahun 2014 tentang Desa.

Undang-Undang Republik Indonesia Nomor 23 Tahun 2014 Tentang Pemerintah Daerah.

Wasistiono, Sadu. (2006). Prospek Pengembangan Desa. Bandung: Fokusmedia

http://www.sp2010.go.id/index.php/navigation/wil ayah. Diunduh pada tanggal 24 maret 2016 pukul 19.35 WIB. 